\title{
Nova descida ao inferno: Patrícia Melo e as mulheres que matam
}

\author{
New Descent into hell: Patricia Melo and the Women who Kill \\ Nuevo descenso a los infiernos: Patricia Melo y las mujeres que matan
}

leda Magri ${ }^{*}$

\begin{abstract}
Resumo
O presente artigo faz uma leitura de Mulheres empilhadas, de Patrícia Melo, a partir de sua relação com $O$ Guesa, de Sousândrade, como estruturante dos vários planos do romance, em especial naquele que toma a floresta como inferno e cura. A partir desse eixo que vai da urbanidade à floresta no contexto dos povos indígenas no Brasil atual, especula-se sobre o Acre figurar como cenário de um novo exotismo na literatura brasileira dos últimos anos. Por fim, aborda-se o gênero policial a partir de um artigo de Josefina Ludmer, "Mujeres que matam", e um olhar para o feminicídio na América Latina.
\end{abstract}

Palavras-chave: feminicídio, Acre, literatura brasileira contemporânea, romance policial.

Abstract

This article reads Patrícia Melo's Mulheres empilhadas along with $O$ Guesa, by Sousândrade, as an organizing principle for the various plains of the novel, but especially for the one in which the forest appears as both hell and cure. From this route that goes from the urban to the forest in the context of indigenous peoples in contemporary Brazil, this text looks into the figuration of Acre as the scene of a new exoticism in recent Brazilian literature. Lastly, this article tackles the detective novel, as discussed by Josefina Ludmer in her article "Mujeres que matam," and its look at femicide in Latin America.

Keywords: feminicide, Acre, contemporary Brazilian literature, police novel.

\section{Resumen}

Este artículo hace una lectura de Mulheres empilhadas, de Patrícia Melo, a partir de su relación con $O$ Guesa de Sousândrade, como estructurante de los distintos planos de la novela, sobre todo en aquel que que considera a la jungla como infierno y cura. A partir de este eje que va de la urbanidad a la jungla en el contexto de los pueblos indígenas en Brasil actual, se hace una especulación sobre si el Acre podría ser el escenario de un nuevo exotismo en la literatura brasileña en los últimos años. Finalmente, se piensa el género policial desde un artículo de Josefina Ludmer, "Mujeres que matan", y se echa una mirada al feminicidio en América Latina.

Palabras-clave: feminicidio, Acre, literatura brasileña contemporánea, novela policial.

Não sei se Patrícia Melo conhece Angélica Freitas, mas no capítulo I de seu livro Mulheres empilhadas, ela usa o mesmo procedimento de "Três poemas com o auxílio do google", nos quais todos os versos começam com uma frase chave para a pesquisa: no primeiro, "A mulher vai", no segundo "A mulher pensa" e no terceiro "A mulher quer". Os poemas colocam diante dos nossos olhos o senso comum, o preconceito, as frases feitas, mas, sobretudo, uma lista de pesquisas já feitas por usuários do google e gravadas ali. A narradora personagem do romance, propositalmente sem nome, para provocar mais facilmente a identificação com qualquer leitora, escreve no google: "Morta pelo" e o resultado imediato é uma lista de frases completadas por: namorado; marido; ex; companheiro; pai; sogro, nesta ordem. O que não só sugere, mas atualiza

\footnotetext{
* Universidade Estadual do Rio de Janeiro (UERJ), Rio de Janeiro, RJ, Brasil. (Dorcid.org/0000-0002-4809-3811. E-mail: iedamagri@yahoo.com.br
} 
o que mostram os casos estudados pela advogada paulista que vai ao Acre cobrir um julgamento de feminicídios e narra o romance.

Mulheres empilhadas tem três planos aparentes desde o início: o primeiro é marcado por números de 1 a 12 e, com excessão de três deles, contam o assassinato de mulheres por seus companheiros e começam pelo título "Morta pelo". São 12 mulheres mortas empilhadas que parecem ser os casos do arquivo da narradora. Muitos deles apresentam nomes completos das vítimas, idade e estado do corpo, além da causa mortis propriamente dita. E são reais, como o assassinato de Engel Sofia Pironato, noticiado nos jornais em 19 de março de 2019 (Gonçalves, 2019).

Somando-se a esse plano, há o da trama propriamente dita e vai de A a X. Nele, a narradora maneja também três planos superpostos: o da advogada que vai ao Acre cobrir os julgamentos; que também é o da mulher que busca entender e dar fim a um relacionamento que parecia ótimo, mas que revelou um homem ciumento e agressivo; e que é, ainda, o da filha que teve a mãe assassinada pelo pai. Este último traço da psicologia da personagem seria a base de sustentação da trama mais profunda do romance, é o que dá sentido a toda busca da personagem-narradora desencadeada pelo tapa na cara dado pelo então namorado. Do tapa à morte. De uma morte a todas as mortes. Esse plano do romance se dá ao mesmo tempo como investigação, seguindo todos os passos do romance policial, seara da autora, e como autodescobrimento. Duas investigações que caminham paralelamente.

As duas investigações se atualizam no terreno do fantástico no terceiro plano do romance, que vai de Alfa a Etá, quando a narradora entra na floresta, toma o ayahuasca, e aos poucos vai encontrando uma legião de aymaras e amazonas vingadoras e se tornando uma delas. Esse plano confronta a dureza dos assassinatos reais e dos fictícios narrados e descritos nos outros planos e dá ao romance uma saída a la Tarantino, onde vaginas voadoras se vingam dos assassinos de suas donas. Os desejos de morte, a frustração e o medo da narradora tomam a forma de uma grande e divertida vingança e nessas páginas o romance vibra mais. Mas não é simplesmente uma vingança barata atualizada pela estética dos videogames ou filmes da Marvel; parece haver uma pesquisa sobre os rituais sagrados dos povos primitivos narrados de muitos modos também na ficção, quando se assava e comia o inimigo para renovar as forças. Uma das cenas parece fazer referência a $O$ enteado, de Saer: as mulheres assam e comem as partes dos corpos dos assassinos de Txupira (o caso que enlaça toda a trama policial do romance), fervem suas tripas, chupam os ossos de suas cabeças e depois bebem até se fartarem.

Se quem narra tem o poder - e especialmente nos romances policiais, em que o narrador é quase sempre homem, seja uma voz onisciente seja encarnada num narrador protagonista que no mais das vezes é o próprio detetive ou seu ajudante -, neste livro de Patrícia Melo, o poder está com as mulheres. Uma mulher investiga, narra, relata, vive experiências e redescobre a si mesma dentro de uma trama de violência que tem a ver com muitas outras mulheres cujas histórias ela expõe num caderno, o caderno de mulheres empilhadas. Outra mulher é a promotora Carla Penteado, que tem papel importante na trama, já que conduz os julgamentos e o principal deles, o assassinato de Txupira, uma garota indígena da família Kuratawa. ${ }^{1}$ Outra mulher forte é a que mais chega perto de desvendar esse crime, Rita, uma jornalista e editora do Diário da Estrela. O escritório para o qual a narradora trabalha parece só empregar mulheres, ou pelo menos só aparecem na trama as mulheres desse escritório paulista. Para cada mulher morta há uma mulher viva que trabalha, investiga e confirma a luta pela igualdade de gêneros. Essa luta se apresenta também na aldeia Ch'aska, mais isolada na floresta, onde a narradora vai em busca de sua cura, levada por Marcos, filho de um estrangeiro com uma indígena e recepcionista do hotel no qual se hospeda a narradora. Nessa aldeia o pajé é uma mulher: Zapira. E sua história é contada no capítulo Beta. Há ainda a avó da narradora, para alargar a representação para todas as idades.

\footnotetext{
${ }^{1}$ Embora não tenhamos encontrado nenhuma aldeia com o nome Kuratawa no quadro geral dos povos indígenas, uma passagem do capítulo N faz a seguinte referência: "Na aldeia dos Kuratawa, cortada pela BR-364 e cercada por ocupações agrícolas, a situação era outra. De madeira nobre ali não tinha mais nada. Nem espaço para roça. Ou para os animais" (Melo, 2019, p. 136-7). Desse modo inferimos ser uma das seis aldeias da etnia Katukina.
} 
Assim como Kuratawa, Ch'aska também não aparece como nome real de um povo indígena do Acre no quadro geral dos povos indígenas, o que dá um enlaçamento todo especial às camadas desse livro, que expõe casos reais de assassinatos de mulheres, o mutirão de julgamento desses casos no Acre, também real, um cenário bastante real de um Estado brasileiro - colocando personagens discutindo inclusive "A questão do Acre" - e uma espécie de panorama ou dedo na ferida quanto à ameaça real de extermínio que sofrem as populações indígenas brasileiras. Assim, ao mesmo tempo que dá os nomes reais das mulheres assassinadas, dá nome fictício às aldeias indígenas. Ch'aska parece fazer uma relação direta à poesia de Sousândrade, autor que também comparece na epígrafe do livro: "Carimbavam as faces/ Bocetadas em flor,/ Altos seios carnudos,/Pontudos,/ Onde há sestas de amor." (Sousândrade, 2012, p. 115; Melo, 2019). A outra epígrafe é de Sarah Grimké, a primeira mulher a escrever um manifesto e ícone da luta pela igualdade de gênero e raça: "I ask no favor for my sex. All I ask for our brethren is that they will take their feet from off our necks" (em português: "Não peço nenhum favor pelo meu sexo. Tudo que peço a nossos irmãos é que tirem os pés de cima de nossos pescoços "). Não é outra coisa o que pede o livro de Patrícia Melo.

A referência a Ch'aska aparece no terceiro canto de $O$ Guesa (e muitas outras vezes depois): "Contigo eu passo a vida/ nos lagos ao luar/ - do meigo cinto aéreo/ Óh Chaska, óh astro!". Uma nota de Luiza Lobo explica: "Chaska: cometa, estrela d'alva; representação incaica da deusa que sempre protege e acompanha o poeta" (Sousândrade, 2012, p. 154).

\section{Mulheres empilhadas e $O$ Guesa}

O plano que remete à epígrafe - aquele que vai de Alfa a Etá e cujo cenário é a mata densa da aldeia Ch'aska e seus rituais purificadores - é todo escrito em diálogo com Sousândrade, sob o signo daquele estado evocado no canto II, o da dança do Tatuturema, dando protagonismo às mulheres e promovendo um inferno que responde à situação contemporânea do extermínio de mulheres. Como se Patrícia Melo partisse desta proposição de Sousândrade e construísse seu próprio cenário infernal indígena:

(AMAZONAS belicosas melhorando a genesíaca superstição:)

- Terra humana, primeiro

Deus fez Eva; e então,

Paraíso sendo ela,

Tão bela,

Fez o homem o Adão (Sousândrade, 2012, p. 135-6).

Vemos crescer, a cada volta da narradora, esse estado das amazonas belicosas, ampliando tanto a belicosidade como a aparência infernal, que vai se afastando das "faces bocetadas em flor" e dos "seios carnudos e pontudos" para faces vingativas, seios extirpados para o corpo melhor acomodar as armas de guerra:

E então aquela coisa quente no meu peito se transformou numa voz cálida, até chegar à Virgem Maria, e depois numa cabeleira farta, e depois numa moça com tanto cabelo quanto poder, munida de arco e flechas, sem o seio esquerdo, que me falou com muita clareza: olha lá o nosso bonde se formando no meio da floresta. Nós, disse ela, nós, mulheres, icamiabas, mães, cafuzas, irmãs, amazonas, negras, Marias, lésbicas, filhas, indígenas, mulatas, netas, brancas, nós brotamos do chão, tremelicando de ódio, vingadoras, enchemos o meu Exucaveirão e avançamos sobre a cidade, carregando pirocas, caralhos de borracha, com poder de fogo, vamos atrás de você, homem mau, homem de bosta, explorador, abusador, estuprador, espancador de mulheres. Assassino. Psicótico. Nosso negócio é com você, matador de mãe. Hoste de demônios (Melo, 2019, p. 26, segundo grifo nosso).

Na terceira visita à aldeia, terceira rodada de ayahuasca, as vozes no peito já são as guerreiras reunidas em torno do lago:

- Tome - disse outra, entregando-me arco e flechas. Só então percebi que o que elas traziam nas mãos não eram tochas de fogo, mas armas de guerra, que cintilavam sob o luar. Muitas haviam extirpado um dos peitos para acomodar melhor as lanças que 
carregavam junto ao corpo. Algumas preferiam amarrar os seios abundantes em faixas de pano. Outras os deixavam livres, peitos pequenos, alguns em flor, peitos murchos, peitos enormes, peitos caídos, peitos Leste-Oeste, alguns assimétricos, em formato de gota, de sino ou redondos (Melo, 2019, p. 94).

E tudo isso em meio à mesma natureza exuberante, com o rio, o lago e a floresta tão encantadores tal qual aparecem no terceiro canto do Guesa, antes ou depois da fúria do rio e do mar no fenômeno da pororoca e contrastando com a descida infernal do Tatuturema do canto II. A cena na qual invoca Chaska se dá quando o poeta está deitado na relva, na paz da visão de um lago:

"Vejo - brincando ao longe

Por cima dos lagos

- Com a ardentia fúlgida

dos lumes da onda a arder,

- Co' o raios, loiros, trêmulos

Da lua formosíssima,

- Co' os vívidos espíritos

Dos ares a correr -

"Dentro do umbroso bosque

Os cervos ruminando,

As flores debruçadas

No lago encantador;

A brisa nas insônias

Na noite branca e bela,

$\mathrm{O}$ vagor arfar das ilhas,

Os ecos ao redor;

“E do palmar os ramos

Fantásticos no espaço,

E nos espelhos d'água

A lua a esvoaçar;

Da natureza à calma,

Pelo silêncio harmônico,

- Enlevo, amor - brincando

Vejo aproximar...

"Gênio risonho, cândido,

De mim por que tremeste?...

Tens da mulher formosa

O mágico poder!

Luz e mudez nos olhos,

Nos ôndulos cabelos

Chamas, que verdes voam

Nos lagos a correr!

[...]

“- Do meigo cinto aéreo,

Oh, Chasca! Oh, astro! Aragens,

Antemanhãs diáfanas

Rolam-te em fogo aos pés!

- Bela visão das luzes...

- Hino dos horizontes...

- Um coração procuro...

- Quem és? Mulher! Quem és?(Sousândrade, 2012, canto III, p. 152-155, grifo nosso).

Essa atmosfera é recriada em Mulheres empilhadas, em que fica latente a pergunta "Quem és? Mulher! Quem és?" É do lago que surge a força suprema em forma de mulher, a "Mulher das Pedras Verdes", que é quem dará acesso ao inconsciente da narradora e a levará pela mão à lembrança do assassinato da mãe. Há um paralelismo evidente:

Ao sair da mata fechada, eu as encontrei. A lua estava nascendo, e elas me aguardavam, percebi imediatamente. Rodeavam um pequeno lago que refletia a luz da lua. De algumas, eu 
só via os cabelos que, de tão grandes e fartos, desciam pelo corpo como cascata, cobrindo o sexo, até os pés [...]. Nua, me juntei a elas ao redor do lago que, refletindo a luz da lua, parecia uma grande poça prateada. Absolutamente nada me impressionava, e esse era o meu espanto: minha familiaridade com aquelas mulheres, com aquele ritual, com o arco e as flechas, que eu sabia manejar. Era como se eu tivesse voltado para a minha terra, um lugar que eu não conhecia, mas de onde eu nunca deveria ter saído. Era a minha tribo. Empunhando armas, entrei com elas no lago, para o ritual de purificação, chamando, com nossos cânticos, pela Mulher das Pedras Verdes. E então ela emergiu das águas, como uma Vênus, nua como nós, cabeluda como quase todas, carregando uma cesta cheia de uma substância mole e verde, de diversos tamanhos, nunca maior do que um ovo e que, tão logo a pegávamos, transformava-se numa pepita de jade. A minha tinha o desenho de uma chave (Melo, 2019, p. 93-95).

Em "Palavras canibais", Antonio Risério diz que "Sousândrade conhecia diretamente a vida indígena, favorecido ainda pelo acaso de ter nascido no Maranhão. Foi talvez o primeiro "moderno" a ter olhos para o Jurupari, mito aborígene da dominação masculina" (Risério apud Dorrico et al., 2018, p. 120), encenado no canto II pela dança do Tatuturema em honra ao deus Jurupari, que seria o deus civilizador dos índios da região amazônica. "Sousândrade", nas palavras de Luiza Lobo, "vê o rito como sinal de decadência dos indígenas" e que "consiste na iniciação sexual à maturidade, coletiva, quando moças e rapazes se recobrem com peles de tatu" (Lobo in Sousândrade, 2012, p. 730, nota).

O mito do Jurupari fala de uma criança, um menino, que nasce de uma virgem e depois desaparece, ainda que ela sinta que ele mama em seus seios durante a noite. Ele volta depois de completar 15 anos para dominar o mundo que antes estava sob o domínio das mulheres. Antes dos Jesuítas, ele era visto como o deus dos pesadelos (por desaparecer durante o dia mas se fazer sentir à noite) e, depois, foi associado ao demônio pelos cristãos. Nessa "tribo" de mulheres descrita na noite do livro de Patrícia Melo, não há lugar para um menino, para um novo Jurupari:

- E se nascem homens? - perguntei.

- Não queremos homens. Não aqui - explicou a mais alta de todas.

- Eles matam rios - expôs aquela. - Matam florestas.

- Eles sabem embocetar - arrazoou uma, lambendo os beiços.

- E se o seu filho for homem? - perguntei à mulher grávida.

Aquela declarou: - Matam mulheres. Matam crianças. Matam os mares.

- Será mulher - respondeu a grávida.

- Temos que começar por alguém - ponderou a Mulher das Pedras Verdes.

- E se for um menino? - insisti com a mulher grávida.

- Entregamos para o pai criar. Na terra deles. Se ele não quiser, matamos. O pai e a criança

- respondeu ela, alisando a barriga imensa (Melo, 2019, p. 97).

Esse mundo onírico que aparece no plano de Alfa a Etá é o de uma terra sem homens. Elas os perseguem e deles se vingam num outro plano, o do mundo dos homens. Assim como em $O$ Guesa, Patrícia Melo se move entre o trágico e o cômico, entre a seriedade e a dureza do mundo real dos feminicídios e dos julgamentos e esse outro plano, cômico, descontraído e vingador:

Txupira está conosco de um jeito muito diferente do que aparece nos laudos periciais, sem ferimentos, sem lesões, sem cacos de vidros no útero, sem costelas quebradas, sem os olhos furados, sem mutilações, está inteira, saudável, exceto pelo fato de que não tem mais seu sexo. Ali puseram a mesma tarja preta que certos censores, em certas épocas, colocam em certos lugares.

- Onde está a vagina de Txupira? - pergunto, e as guerreiras me contam que a vagina de Txupira é agora livre, voadora como um pássaro, e sua missão é perseguir e aterrorizar os assassinos.

- É o que costumamos fazer com os praticantes de sexo ilícito - me explicam, rindo. Elas realmente gostam dessa história. Como riem. Gargalhante, uma delas me diz que, durante os ataques, a glande dos clitóris voadores endurece e se transforma num bico tão duro e resistente quanto uma broca, "uma versão mais mortal da vagina dentata", diz ela. Imagine que eles, os espancadores, os pegadores, os terroristas sexuais, estão, por exemplo, 
na sala de aula, e de repente slach, levam uma vaginada de Txupira na testa, que fura seus cérebros com a mesma eficiência de uma furadeira elétrica. Mas antes a vagina de Txupira paira acima deles e mija sobre suas cabeças (Melo, 2019, p. 120-21).

Esse plano, onírico, delirante, vingador, funciona como um respirador no meio dos assassinatos e julgamentos. É um restabelecedor de forças, inteiramente encerrado na mente da narradora e liberado no ritual do ayahuasca. É como ela vai ao encontro de si mesma. Mas tem uma dimensão na realidade do relato: para acessar esse mundo da mente é preciso viajar várias horas, entrar na profundeza da mata e encontrar uma aldeia indígena inteiramente preservada da ânsia civilizadora. E essa questão recebe um tratamento quase documental, pois há uma atenção permanente ao contexto brasileiro atual de ataque e extermínio dos índios e usurpação de suas terras.

Assim como n'O Guesa, em Mulheres empilhadas há um paralelo entre um mundo indígena belo, puro e bom (em Sousândrade aquele de antes da colonização, que traz a decadência, simbolizada pela introdução da agropecuária, como se vê no canto II, mas também aquele mundo cantado pela tradição indigenista brasileira anterior) e um outro, decadente, tornado infernal depois da colonização:

São muitos arraiais, nações diversas,

São filhos do ócio, que ora despertaram

Na ambição vária (as multidões dispersas

Do arau' medroso às águas se arrojaram):

Tumultuados volvem as areias,

Esquadrinham, revolvem, amontoam,

Com a sede dos que da terra as veias

De suor não regam, vozes não entoam

Na sossegada lavra, esperançosas

Tangendo o boi do arado.

O povo infante

O coração ao estupro abre ignorante

Qual às leis dos cristãos as mais formosas.

Mas, o egoísmo, a indiferença, estendem

As eras do gentio; e dos passados

Perdendo a origem cara estes coitados,

Restos de um mundo, os dias tristes rendem.

Quanta degradação! Razão tiveram

Vendo, os filhos de Roma, todos bárbaros

Os que na pátria os olhos não ergueram,

Nem marcharam à sombra dos seus lábaros.

O estrangeiro passa: que lhe importa

A magnólia murchar, se ele carece

Tão só dalgumas flores?... Anoitece

Num sono aflito a natureza morta!

[...]

Destino das nações! Um povo erguido

Dos virgens seios desta natureza,

Antes de haver coberto da nudeza

O cinto e o coração, foi destruído:

E nem pelos combates tão feridos,

Tão sanguinárias, bárbaras usanças;

Por esta religião falsa d'esperanças

Nos apóstolos seus, falsos, mentidos. 
Ai! Vinde ver a transição dolente

Do passado ao porvir, neste presente!

Vinde ver do Amazonas o tesoiro,

A onda vasta, os grandes vales de oiro!

Imensa solidão vedada ao mundo,

Nas chamas do equador, longe da luz!

Donde fugiu o tabernác'lo imundo,

Mas onde ainda não abre o braço a cruz! (Sousândrade, 2012, p. 108-112, canto II).

No livro de Patrícia Melo, a aldeia Kuratawa, cortada pela BR-364, mostra a penúria e a decadência miserável do indígena brasileiro incorporado à urbanidade, enquanto a aldeia Ch'aska, mais entranhada na mata, de difícil acesso, e tendo como pajé uma mulher, consegue manter seus rituais sagrados, inclusive para curar outros povos que a procuram, como é o caso da narradora. Mas não foi sempre assim. No capítulo $\mathrm{P}$, Marcos, filho de mãe indígena, conta que dos 800 índios que viviam ali no segundo ciclo da borracha sobraram apenas 57. Todos os que são os Ch'aska de hoje vieram desses 57 . Num momento da história, todos se tornaram evangélicos, todos passaram muita fome e só conseguiram se reerguer quando decidiram retomar suas crenças, sua língua e sua cultura, quando promoveram o renascimento da aldeia como "povo da floresta". O contraste com a situação dos Kuratawa ilumina aquela visão de Sousândrade e a atualiza: a decadência do povo indígena é promovida pela destruição de sua cultura. O capítulo $\mathrm{N}$ descreve os Kuratawa e, de quebra, diz muito da promoção dessa decadência pelo atual governo brasileiro. "A escola da aldeia, vim a saber depois, desativada desde o início do novo governo" (p. 138) e "Mas não tenho esperança, vivemos novos tempos [...] Essas famílias nunca aceitaram a demarcação das terras indígenas. E agora se sentem autorizadas a entrar nas aldeias e a ameaçar" (p. 181) são exemplos da visão direta, proporcionada pelo livro, da situação política brasileira do presente.

\section{Acre, um novo exotismo?}

$\mathrm{O}$ capítulo $\mathrm{N}$ conduz o leitor a entrar na aldeia (graças também à pesquisa da jornalista Emily Sasson Cohen, que esteve no Acre e nas aldeias, como fica registrado nos agradecimentos) e a ver a situação dos indígenas que estão mais próximos da urbanidade, que perderam sua condição de povo da floresta, já que onde estão situados, próximos da rodovia e das terras cultivadas pela agricultura predatória da região, não há mais caça, há pouco peixe e poucas frutas. Ou seja, os Kuratawa aparecem no livro envoltos em montes de garrafas pet, tomando café com muito açúcar, com cárie nos dentes desde a infância.

Eu não era uma turista entusiasmada esperando um espetáculo folclórico de pingentes e penachos. Já estava em Cruzeiro do Sul havia tempo suficiente para saber das dificuldades que as comunidades indígenas enfrentavam. Mas os Kuratawa sequer pareciam indígenas. Eram apenas pobres. Abandonados. Fui tomada de uma súbita angústia ao ver toda aquela precariedade. $\mathrm{O}$ aumento da população local fez com que a aldeia tivesse seus espaços para agricultura reduzidos. Quase mais ninguém plantava mandioca ou feijão. A maioria só comia produtos que compravam nos supermercados da cidade, com o dinheiro que recebiam do Bolsa Família. Muitos sobreviviam de um artesanato simples, vendido na cidade (Melo, 2019, p. 137).

Mais adiante, um dos personagens reflete sobre a condição dos indígenas a partir da "Questão do Acre", como ficou conhecida a disputa entre Brasil e Bolívia pelo território, que acabou sendo comprado pelo governo brasileiro por dois milhões de libras esterlinas. O que fica patente é que as mesmas famílias de coronéis cearenses que fundaram o Acre, escravizaram ou mataram os indígenas, compraram o território e nele mandam até hoje: "Até hoje essa gente não se conforma com a demarcação das terras indígenas. Hoje o sonho deles é retomar os territórios, mas agora pensando no agronegócio, querendo queimar a terra pra fazer pasto" (Melo, 2019, p. 140). 
Um simples olhar para o quadro geral dos povos indígenas mostra que há aldeias em quase todas as regiões brasileiras e que em todas elas a situação se repete. Por que, então, é o Acre que figura como cenário nesse livro? A narradora dá uma explicação logo nos primeiros capítulos: quer participar dos julgamentos de feminicídio que ocorrem em todo o Brasil na mesma semana, mas por questões pessoais quer ir para a cidade mais distante de São Paulo. Lhe dizem: é o Acre. E por isso ela vai pra lá. Quase ao acaso, portanto. Já a explicação da autora se dá pela proximidade da floresta. Ela queria unir o julgamento e a floresta, o feminicídio e o massacre indígena. Duas das minorias mais atacadas no Brasil atual. Poderia ter o mesmo efeito se escolhesse o Amazonas, cenário dos cantos II e III de O Guesa que lhe servem de inspiração, ou Rondônia ou Pará? Certamente. Mas o Acre figura como uma das capitais com a maior taxa de feminicídio do Brasil. E, curiosamente, aparece em dois outros livros de mulheres nos últimos anos. Em Ruina y leveza, de Julia Dantas, e em Acre, de Lucrécia Zappi.

Em Ruina y leveza é apenas uma pequena referência, mas me interessa porque diz um pouco sobre como aparece esse estado no imaginário do brasileiro. A narradora-protagonista, Sara, está em Cuzco, onde conhece Carmem que, depois de saber a nacionalidade de Sara, diz que já esteve em Rio Branco. "Precisei resgatar as aulas de geografia do primeiro grau", diz a narradora. "Rio Branco, capital do Acre? Por que alguém no mundo pensaria em ir ao Acre? (Dantas, 2015, p. 79). Essa passagem acaba reverberando aquela do momento em que a narradora de Mulheres empilhadas interage pela primeira vez com Marcos, o atendente de seu hotel em Cruzeiro do Sul e que depois se tornará uma personagem importante na história: “- Agora então você já pode dizer para os seus amigos paulistas que o Acre existe" (Melo, 2019, p. 18).

Em Acre, de Lucrécia Zappi, a referência ao estado parece remeter à ideia de violência selvagem contraposta à violência urbana de São Paulo. Nelson, a personagem que volta do Acre, é uma espécie de portador do mal: um homem sem escrúpulos, violento, fugitivo da polícia e das milícias ou máfia acreana. A primeira referência ao Acre aparece assim:

Mas você esteve mesmo no Acre?, Ana perguntou, sem prestar atenção em Marcela. Não era lá que você estava?

Acre. É, respondeu.

Fazendo o que lá? Deve ter casado, Ana perguntou com um sorriso cristalino.

É, essas coisas. Cheguei quando aquilo era meio deserto. [...]

O cara devia ter fugido do Acre, pensei. A impressão que tive quando falou foi a de um lugar cheio de seringueiras e mais nada (Zappi, 2017, p. 71).

Aos poucos o leitor é apresentado ao passado violento de Nelson. Ele é uma espécie de carrasco do narrador, e a violência do passado é atualizada com sua volta a São Paulo. A personagem funciona como símbolo de uma violência que não pode ser contida e que envolve outras personagens, desencadeando muitas cenas que vão de assédio a mulheres ao possível assassinato da mãe.

As personagens ficam muito interessadas no Acre e, ao descobrir que Nelson deixou mulher e filhos, querem saber quais são suas perspectivas ali. Oscar, o narrador, pergunta: "Deve ser meio ruim mesmo ela ficar sozinha com os filhos num lugarejo selvagem lotado de insetos. Parece que é isso, ou não?" Ao que Nelson responde: "É, Oscar. Brejo, chuva morna e uma vida mais ou menos criminal, mesmo com uma casa boa. É essa a perspectiva que ela tem ali" (Zappi, 2017, p. 165) Mais tarde, aparece uma síntese do que a personagem entende pelo Acre: "O Acre, falou Nelson, abrindo os braços no ar, é o mundo da borracha, o das seringueiras de Luiz Gálvez, o Imperador. Imagina, Oscar. Do ouro negro da borracha passaram ao ouro vermelho do mogno. E dos Ipês". (Zappi, 2017, p. 169) É o mundo do mercado negro da madeira, com o qual a personagem estava envolvida. O Acre, então, aparece como um grande mercado clandestino: o do tráfico de madeira.

O principal crime de Mulheres empilhadas, o que durante toda a trama parecia ser um crime sexual, acaba por se revelar ligado ao tráfico de drogas. Assim, nos três livros, o Acre aparece ou como um lugar sobre o qual nada se sabe ou como o lugar mais violento do Brasil. No livro

\footnotetext{
${ }^{2}$ Ver o artigo de Ana Cristina Carmelino (2016), que busca refletir sobre esse imaginário via análise do discurso. Uma versão mais divertida do mesmo assunto pode ser acessada em Dehò (2018).
} 
de Lucrécia Zappi, fonte de uma violência sem contenção, símbolo de um mal que pode desencadear mil outros males. É um livro totalmente paulistano. As personagens são paulistas, o cenário é um bairro de São Paulo. No limite, é um livro que joga com esse imaginário do Acre como figuração de um mundo distante, desconhecido e violento. Selvagem, em última análise. De uma violência incompreensível para os padrões urbanos. É também um imaginário do desconhecimento, quase lendário. E, poderíamos dizer, uma ponte na qual São Paulo exporta o bandido para o Acre e depois ouve suas histórias de horror. O título do livro remete a esse ponto de fuga, onde estaria, distante, mas comunicável, toda a incompreensão da violência desmedida. Em todas as partes, o Acre como uma descida ao inferno.

É interessante como de lugar inexistente, do qual nunca se fala, de repente esse estado passa a figurar como cenário na literatura brasileira contemporânea. Essa evidência estaria apontando para a construção de um novo exotismo? Tanto as favelas cariocas e paulistas quanto a selva amazônica já não constituem novidade. $\mathrm{O}$ Acre pode funcionar como fronteira, como o desconhecido que se quer desvendar e que pode abrigar temas como feminicídio, tráfico e condição dos indígenas no Brasil, uma literatura que se alinha, tematicamente, a um filão da literatura latino-americana. O Acre é o nosso deserto?

\section{Feminicídio e gênero policial}

Quem escreveu de maneira mais contundente até agora sobre o extermínio das mulheres foi Roberto Bolaño, em seu 2666, que mostra um grande cemitério a céu aberto onde jazem em covas abertas, mutiladas, centenas de mulheres, cujos assassinos nunca foram punidos. O cenário, real, é Ciudad Juarez, renomeada como Santa Teresa, na fronteira do México com os Estados Unidos e os crimes reais expostos no livro aconteceram na década de 1990. O livro de Sérgio Gonzáles Rodrigues, Huesos en el deserto, aparece declaradamente no livro de Bolaño como um precursor, e seu autor figura como personagem que investiga os crimes. Bolaño também rende homenagem em seu livro a três personagens mulheres importantes no trabalho de investigação e de enfrentamento da sociedade mexicana e seu modo de tratar os crimes: a primeira menção é a uma "jornalista de Il Manifesto" cuja matéria reverbera na Itália (Bolaño, 2010, p. 52); a segunda já é uma jornalista com nome, Guadalupe Roncal, do DF, e atua como detetive ou "jornalista secreta" que "conhece tudo o que diz respeito aos assassinatos" (p. 290); e a terceira é uma deputada, Azucena Esquivel Plata, que dá um longo depoimento ao jornalista Sérgio Gonzáles (o personagem de 2666) e entendeu que a criminalidade tem seus laços com a política.

O ensaio de Rita Laura Segato (2005) "Território, soberania e crimes de segundo estado: a escritura nos corpos das mulheres de Ciudad Juarez" dá uma dimensão da complexidade que envolve a investigação desses crimes de feminicídio no México e, por conseguinte, faz aparecer o entrelaçamento entre verdade e ficção no livro de Bolaño, não porque trate dele, mas porque mostra num ensaio a faceta perversa do enlaçamento entre o Estado, o tráfico de drogas e o mais simples preconceito contra a mulher. Sabe-se que "A parte dos crimes", foi a última a ser escrita por Bolaño e que ficou sem sua revisão definitiva. Ainda assim, as duas páginas que mostram os policiais encarregados das investigações tomando café da manhã e contando piadas machistas são um exemplo bruto da perversidade e do descaso com que é tratado o problema (Bolaño, 2010, p. 527).

Desde a publicação do livro de Bolaño, em 2004, logo após a morte do autor, os crimes contra mulheres tem ganhado visibilidade e a sociedade tem exigido algum tipo de combate. Um dos esforços, no Brasil, tem sido os mutirões, dos quais fala Patrícia Melo em seu livro. No entanto, as estatísticas mostram que é um tipo de crime que não para de crescer.

O diferencial do livro de Patrícia Melo não é a notícia sobre os feminicídios, a denúncia em si. É justamente esse plano no qual as mulheres matam. Um plano que tensiona e torce a realidade das mulheres brasileiras. No plano mais "realista" do romance já aparece a condição das mulheres vítimas mesclada com a tomada dos lugares concebidos como "dos homens", como é o caso do mundo do direito, por exemplo, quando Carla, a promotora, diz:

Quando fui transferida para cá, não sabia porra nenhuma sobre o Acre, então comecei a ler tudo o que me caía nas mãos. Minha sensação era a de que eu tinha voltado para os bancos 
escolares, e estava estudando a história do Brasil de novo: terra de índio, floresta virgem, homem branco chega fodendo com tudo, aquela coisa que a gente conhece bem. Só que estamos falando de ontem. Século vinte. Os caras vinham para cá, do Nordeste, fugindo da seca, atrás de trabalho nos seringais, e vinham sozinhos. Sem mulher. Matando indígenas adoidado. Mulher aqui era artigo de luxo. Aqui se roubava mulher. Do pai, do marido, das aldeias. E elas eram vendidas. Comprava-se uma mulher ao preço de quinhentos quilos de borracha. Então eu pensei, porra, eu, porra, eu, com meu jeitinho nada meigo, eu, com meu sangue quente, eu, que vivo do meu dinheiro, que não abaixo minha crista para nada, eu com minha língua afiada, solteira, sem filhos, com meu coração cheio de ódio para dar, vou agora trabalhar nesta terra onde ainda ontem se caçava mulher ali na mata, no laço? Onde mulher era vendida, encomendada, roubada? Logo eu? Isso não vai ser bom para o Acre, pensei com meus botões - falou, soltando uma gargalhada sonora, quase escandalosa. Gosto de ser uma pedra no sapato dessa gente (Melo, 2017, p. 44-45, grifo nosso).

As mulheres vivas que aparecem no livro, que atuam no livro, são mulheres fortes, que não dependem dos homens nem para resolver os crimes, nem para ter satisfação pessoal, prazer ou felicidade. Elas também não precisam atuar nem no papel de mães ou virgens, por um lado, nem no de prostitutas ou femme fatale, por outro, papeis clássicos reservados às mulheres na ficção. Não são musas. São mulheres modernas, num mundo moderno no qual os papeis estão em aberto. E são mulheres num romance policial escrito por uma mulher. Isso, no Brasil, é uma novidade.

\section{Mulheres que matam}

Esse é o título de um artigo de Josefina Ludmer, publicado em 1996, e que investiga o aparecimento, na Argentina, das primeiras mulheres que cometem delitos na literatura.

"Mulheres que matam": não apenas indica uma ação feminina no crime, mas é sobretudo uma expressão que se refere a um tipo de mulher que produz uma morte figurada nos homens porque possui "algo", armas. A metáfora está inscrita na linguagem: uma matadora de homens, uma "killer woman". Certas formações linguísticas com marcas de crime constituem relatos e histórias, e também constituem a própria "realidade": o direito, a medicina, a vida cotidiana, o erotismo. Uma espécie de "crime" feminino inscrito na língua, colocado numa história, numa corrente e numa rede de correlações: é o que iremos analisar (Ludmer, 1996, p. 782, tradução nossa).

A genealogia que Josefina Ludmer faz vai de La bolsa de huesos, de Eduardo Holmberg, de 1896, até La prueba, de César Aira, de 1992.

A primeira assassina, Clara, comete seus crimes na faculdade de medicina, dando a suas vítimas um veneno ainda desconhecido pela classe médica para, depois, retirar delas uma costela. Signos femininos, diz Ludmer. Quando descoberta por um detetive, acaba escapando à justiça do Estado, pois ele, concluindo que ela sofre de histeria, condena-a a beber de seu veneno. A torção que a ficção dá na realidade, diz Josefina Ludmer, é que esse primeiro caso de delito de uma mulher coincide com a entrada da mulher nos cursos de medicina na Argentina e com o contexto maior do estudo da histeria por Charcot, na França. O segundo crime cometido por uma mulher na literatura argentina aparece em Arlt, numa peça de teatro, Saverio el cruel, de 1936. Numa farsa no palco, ela acaba matando o "ditador latino-americano que quer dominar o mundo" (Ludmer, 1996, p. 796, tradução nossa). Em “Emma Zuns”, de Borges, escrito em 1946, "Emma é a Virgem justa, enviada por Deus, e também a operária que se levanta contra o patrão durante a greve, e também aquela que mata um judeu que trabalha no sábado, ou simplesmente aquela que mata um judeu. Aquela que mata representa todas as justiças: a de Deus, a do pai, a justiça de classe, racial e sexual" (Ludmer, 1996, p. 790, tradução nossa). Em Boquitas pintadas, dos anos 1960, de Manuel Puig, Raba mata o policial com quem teve um filho e que nunca o assumiu. E, aqui, diz Ludmer, o delito aparece tensionando as classes sociais, muito marcadas no romance. Bastaria lembrar que Mabel, a patroa, é quem se une a Raba para impedir sua prisão. E de novo, a assassina não merece a justiça do Estado. Na novela de Aira, que deveria se chamar "crimes no supermercado", segundo Ludmer, duas adolescentes lésbicas matam os 
consumidores de um supermercado, colocando em cena a justiça das mulheres contra o mundo moderno capitalista.

O que ocorre nessa série, diz Ludmer, é que é negada à mulher a voz em primeira pessoa. Quem narra os crimes são os homens, em todos os casos. Para encontrar um relato em primeira pessoa de crime de mulher que mata, ela precisou ampliar a pesquisa para a América Latina e assim, o encontrou no mexicano Ángeles Mastreta, em Arráncame la vida. Ela defende que essa passagem para primeira pessoa é crucial, porque define o sentido do texto em outro lugar:

As histórias de mulheres que matam, encadeadas, constituem a todo o momento a "incriminação" de uma representação feminina com poder, que não recebe justiça estatal. Mas, dependendo de como é lida, ou como é contada, seja pela vítima, pelo cronista, ou pela que mata, ou dependendo de que perspectiva a cadeia é vista, o significado da subtração da justiça estatal varia, porque, naquelas que matam, o gênero é quem decide o sentido da representação. Para o detetive médico, os estudantes de medicina, ou o pobre quitandeiro, aquela que mata vira uma mulher neurótica e louca, e recebe uma condenação médica e social, não jurídica: é o caso de Holmberg e, talvez, o de Arlt. Quando contada a partir da voz feminina, ou de outro gênero, também literário, a mulher que mata escapa da justiça estatal porque faz justiça política e sexual, mata um "criminoso" e recebe um prêmio libertador (Ludmer, 1996, p. 794, tradução nossa).

O texto de Ludmer nada fala sobre autoria feminina, sequer se pergunta sobre o que aconteceria se um desses textos ficcionais que colocam em cena delitos de mulheres fosse escrito por uma mulher. Teria alguma variação significativa? Parece-me que Mulheres empilhadas, ao dar o poder de vingança a uma mulher, dotada pelo poder imaginativo feminino e, portanto, liberto para transformar em armas os clitóris das vítimas de delitos sexuais, faz dar mais uma volta nesse parafuso apontado por Ludmer. Mulheres que matam, mas mais do que isso, mulheres que se vingam. Mulheres que devoram suas vítimas.

Embora acredite que o gênero policial não carece de nenhum tipo de engajamento ou função utilitária, mas cumpre bem sua função sendo simples entretenimento, no caso do livro de Patrícia Melo, acabo concordando com o que diz Julio Pimentel Pinto no prefácio ao livro Acerto de contas: treze histórias sobre crime \& América Latina, organizado por Daniel Galera: que a literatura policial pode ser "um diagnóstico terrível que pode até ajudar a criar, em tempos sombrios, alguma consciência" (Galera, 2017, p. 13).

Pelo simples fato de fazer o tema chegar a um público que não é aquele que procura por notícias, ou seja, o vasto número de leitores de romances policiais, o livro, com seu "diagnóstico terrível", acaba impelindo os leitores à consciência do problema e gerando um desconforto que deve se desdobrar em, no mínimo, algumas formas de comentário, o que multiplica ainda mais seu alcance. E, ainda mais plausivelmente pelo que diz Josefina Ludmer,

O romance policial fala sobre crime e delito. Que outros discursos falam sobre crime e delito? Discursos penais, o jornalismo fala disso também etc.; mas qual seria a peculiaridade do gênero policial? Sua situação comunicativa, ou seja, a existência de um narrador numa determinada situação específica que se comunica com outro destinatário, que estabelece com uma língua determinada uma situação de comunicação específica. Isso não está no corpo penal, nem no discurso jornalístico etc.; falar sobre o crime, ou sobre o delito, desse ponto de vista, dessa situação de comunicação específica, faria com que o que é dito sobre o crime seja diferente (Ludmer, 2016, p.170-171, tradução nossa).

Se até pouco tempo Patrícia Melo vinha sendo muito criticada pela falta de novidade, pela monotonia de seus livros sempre iguais, o tratamento que dá a essa temática a coloca noutro patamar como escritora de romances policiais.

No entanto, não creio que, como diz Julio Pimentel Pinto, precisemos, enquanto leitores, perceber que a literatura policial "não é entretenimento". Sim, é entretenimento também. E isso não a diminui. Enquanto denúncia ou "mostração" da realidade social das mulheres no Acre, em São Paulo ou no Brasil, o livro de Patrícia Melo seria apenas banal. O que faz com que seja interessante é justamente a torção que faz no gênero, abrindo-o à fantasia mais descarrilada, inscrevendo-o sob o signo de $O$ Guesa e dando à mulher também um lugar reverso ao da vítima. 


\section{Referências}

BOLAÑO, Roberto (2010). 2666. Tradução de Eduardo Brandão. São Paulo: Companhia das Letras.

CARMELINO, Ana Cristina; SILVEIRA, Karine (2016). O Acre não existe? Nas desnotícias, não. Linguagem em (Dis)curso, Tubarão, v. 16, n. 3, p. 433-448. Disponível em: http://www.scielo.br/pdf/ld/v16n3/15187632-ld-16-03-00433.pdf Acesso em: 23 mar. 2020.

DANTAS, Julia (2015). Ruína y leveza. Porto Alegre: Não Editora.

DEHÒ, Maurício (2018). "This Is Acre": Youtubers acreanos bombam brincando com "lendas" do estado. Bol, Entretenimento, 15 jun. On-line. Disponível em: http:/ / bit.ly/3c15llM Acesso em: 23 mar. 2020.

DORRICO, Julie et al. (Org.) (2018). Literatura indígena brasileira contemporânea: criação, crítica e recepção. Porto Alegre, RS: Editora Fi.

GALERA, Daniel (Org.) (2017). Acerto de contas: treze histórias sobre crime \& América Latina. Tradução de Eduardo Brandão. São Paulo: Companhia das Letras.

GONÇALVES, Filipe (2019). Mulher é assassinada por ex e tem corpo colocado em geladeira no ABC. G1, Bom dia SP, São Paulo, 19 mar. On-line. Disponível em: https://g1.globo.com/sp/saopaulo/noticia/2019/03/19/mulher-e-assassinada-por-ex-e-tem-corpo-colocado-em-geladeira-noabc.ghtml Acesso em: 12 jan. 2020.

LUDMER, Josefina (1996). Mulheres que matam. Revista Iberoamericana, v. LXII, n. 176-177, p. 781-797, jul./dez.

LUDMER, Josefina. (2016). Clases 1985. Algunos problemas de teoría literaria. Edição e prólogo de Annick Louis. Epublibre.

MELO, Patrícia (2019). Mulheres empilhadas. São Paulo: Leya.

SEGATO, Rita Laura (2005). Território, soberania e crimes de segundo Estado: a escritura nos corpos das mulheres de Ciudad Juarez. Rev. Estud. Fem., Florianópolis, v. 13, n. 2, p. 265-285. Disponível em: https://www.scielo.br/pdf/ref/v13n2/26882.pdf. Acesso em: 26 fev. 2020.

SOUSANDRADE, Joaquim, de (2012). O Guesa. Organização, introdução e notas de Luiza Lobo. Rio de Janeiro: Ponteio; São Luís, Maranhão: Academia Maranhense de Letras.

ZAPPI, Lucrécia (2017). Acre. São Paulo: Todavia.

\section{Nota}

Este artigo faz parte da pesquisa "Literatura brasileira e latino-americana: questões de inserção no cenário contemporâneo", apoiada pela Fundação de Amparo à Pesquisa do Estado do Rio de Janeiro (Faperj) no programa Jovem Cientista do Nosso Estado (JCNE). 